\title{
Pensononowoor
}

2021, vol. 85, 92-104

https://doi.org/10.12657/denbio.085.009

\author{
Md. Aktar Hossain*, Joyeta Dey, Mohammed Abdur Rahman
}

\section{Propagation of threatened climber species Entada rheedii Spreng. - a medicinal plant with extremely thick and hard seed coat}

Received: 20 June 2020; Accepted: 30 March 2021

\begin{abstract}
The study explored propagation techniques of Entada rheedii Spreng., a threatened medicinal climber species with extremely hard seed coat. Propagation trials included both pre-sowing treatments of seeds for germination and clonal propagation by stem cutting. Pre-sowing treatments included (a) soaking of both cut (notched) and uncut (intact) seeds in water for 0 h, 24 h, 48 h, and $72 \mathrm{~h}$ and (b) immersion of intact seeds in 5\% acetone solution for $5 \mathrm{~min}, 10 \mathrm{~min}$, and $20 \mathrm{~min}$ before sowing in germination media in polybags. On the other hand, stem cutting involved treating the summer or autumn cuttings with $0 \%$, $0.4 \%$, and $0.8 \%$ IBA solution before rooting in non-mist propagator. Notched seeds soaked in water for 48 $\mathrm{h}$ showed the fastest seed germination with the highest germination percentages (73.3) and better seedling growth in terms of plant height, collar diameter, leaf number and total dry mass followed by notched seeds soaked in water for $72 \mathrm{~h}$. The slowest germination and the lowest germination percentage (3.3), as well as the poorest growth performance was for intact seeds without any treatment. The highest rooting percentage with maximum number of roots (36.6) was obtained from the summer cuttings treated with $0.4 \%$ IBA solution followed by autumn cuttings with $0.8 \%$ IBA and the lowest ( $43.3 \%$ and 8.3 roots) was for summer cuttings in control. The factors also dictated the survival and growth performance of rooted cuttings in the nursery conditions. The outcomes of these trials i.e., notched seeds soaking in water for $48 \mathrm{~h}$ will help to enhance the propagation of this valuable medicinal plant species.
\end{abstract}

Keywords: Entada rheedii, germination potential, growth performance, pre-sowing treatments, rooting ability, rooted cuttings

Addresses: M. A. Hossain, J. Dey, Institute of Forestry and Environmental Sciences,

University of Chittagong, Chittagong-4331, Bangladesh,

e-mail: aktar_forestry@hotmail.com; aktar@cu.ac.bd; (1) https://orcid.org/0000-0002-5273-4837

M. A. Rahman, Divisional Forest Officer, Bagerhat Social Forestry Division, Bagerhat -9300, Bangladesh, e-mail: rahmanacf@gmail.com

*Corresponding author

\section{Introduction}

The genus Entada (Family: Fabaceae; subfamily: Mimosoideae) consists of 30 tropical and subtropical species (Luckow, 2005; Yang et al., 2005; Ohashi et al., 2010; Okba et al., 2013; Hoveka, 2017) including Entada rheedii Spreng. (Synonyme: Entada rheedei,
Entada phaseolides or Entada pursaetha (Cleversley, 2002; Awale, 2005; Ohashi et al., 2010). Entada rheedii Spreng. is a large woody twisted liana commonly known as Adenanthera Gogo, African Dream Herb, Balugo, Dipai, Dream Bean, Garambi, Garbi, Gogo, Gogong-bakai, Kakavalli, Kessing, Lipai, Matchbox Bean, Sea Bean, Sea Heart, Snuff Box Sea Bean, 
Tamayan in different areas throughout the tropical and subtropical regions in Madagascar, Southern Africa, Asia, and Australia (Cleversley, 2002; Awale, 2005; Yang et al., 2005; Ohashi et al., 2010). In Bangladesh, it grows naturally in the hill forests of Chittagong, Chittagong Hill Tracts, Sylhet and Cox's bazar and Sundarban Mangrove forests. It reaches up to $40 \mathrm{~cm}$ in diameter (Ohashi et al., 2010) having compound leaves bipinnate with the primary axis terminating in bifid tendrils, inflorescences long $(12.5-15.5 \mathrm{~cm})$ with whitish pleasantly perfumed small $(5 \mathrm{~mm}$ in diameter) flowers. Pod is about $60-70 \times 6.5-9.5 \mathrm{~cm}$ but sometimes up to $110 \mathrm{~cm}$ in length, segmented (each segment 7.5-9.5 cm long) (Fig. 1). Endocarp is woody, seeds are brown, flattened, sub orbicular, flat, $3.5-5.7 \mathrm{~cm}$ long, $3.5-5 \mathrm{~cm}$ wide, $2-2.5 \mathrm{~cm}$ thick and are hollowed out and filled with snuff and often called as 'snuffbox sea beans' (Siddhuraju et al., 2001). Testa is up to $2 \mathrm{~mm}$ thick, very hard; adaxial surfaces of the cotyledons do not touch to form a hollow structure (Ohashi et al., 2010). Mature seeds are rich in protein $(26.8 \%)$, lipid $(9.5 \%)$, fiber $(15.7 \%)$, ash (5.4\%) and carbohydrates (42.5\%) (Vadivel et al., 2008). The high level of protein (with major proportion of albumin proteins), have a balanced amino acid (23.5\%) composition, lipid (3.1-10.8\%) with predominant unsaturated fatty acids and digestible starch (Janardhanan \& Nalini, 1991; Mohan \& Janardhanan, 1993; Vijayakumari et al., 1993; Banerjee \& Dixit, 1998; Siddhuraju et al., 2001).

Mature and immature fruits, shoots and leaves of the plant are favorite foods for large herbivores
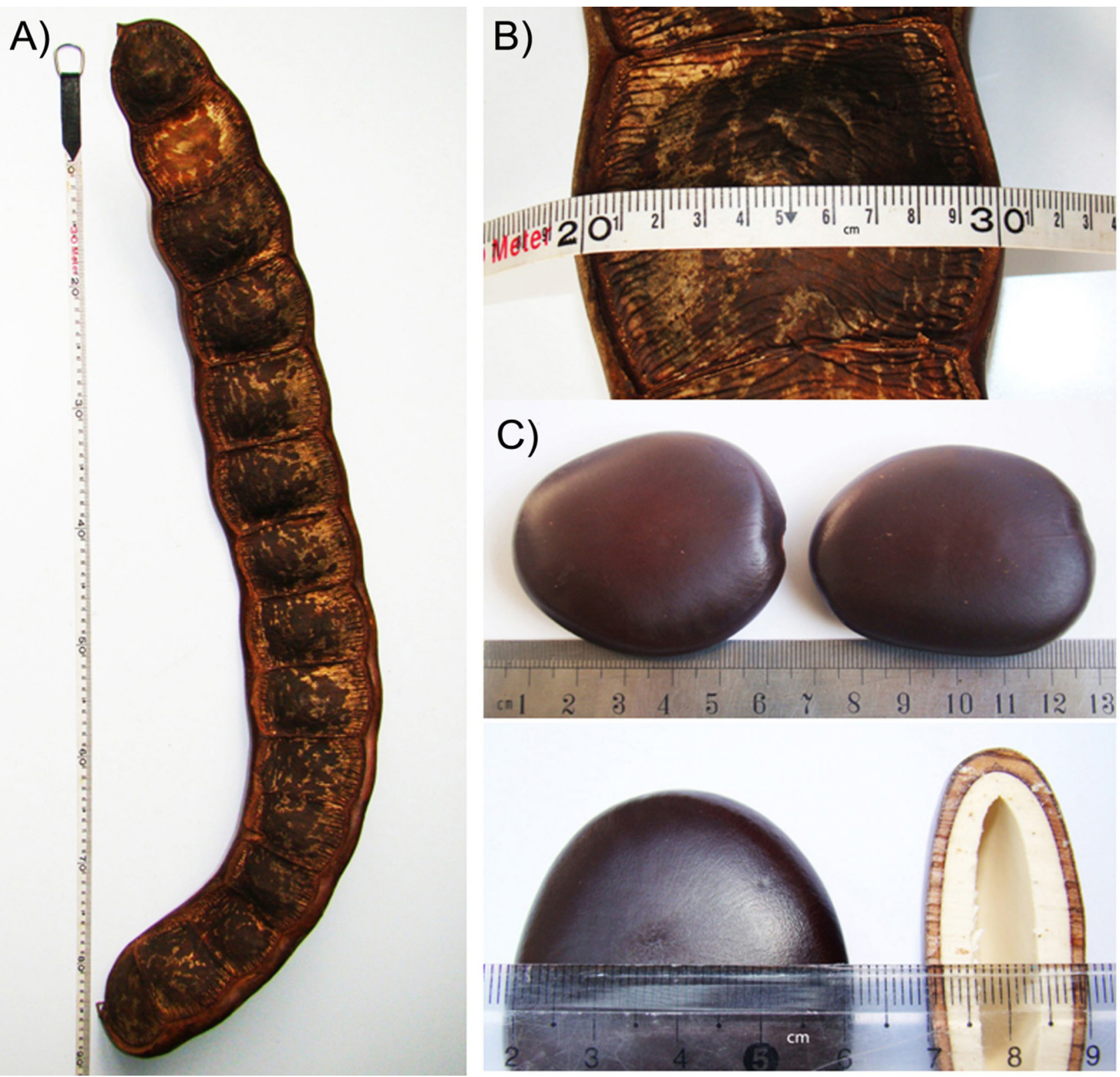

Fig. 1. Fruit length (A), breath (B), seed size and seed coat thickness (C) of E. rheedii 
including elephants. Karib tribes of Assam and Oceanic group of tribes such as Onges and Great Andamanese in India eat boiled seeds. Northeast Indian tribal sectors such as Garo, Khasi, Naga and Kanikkars of Tamil Nadu and Kerala eat soaked seed kernels upon roasting/boiling (Mohan \& Janardhanan, 1993; Siddhuraju et al., 2001; Janardhanan et al., 2003). The half-ripened seeds are coffee substitute in some parts of South America (Janardhanan \& Nalini, 1991; Siddhuraju et al., 2001).

In Southeast Asia, especially in the Philippines, India, Bali, Java and Sumatra the vine's leaves, bark, roots and seeds are used in different ways to cleanse fresh wounds, heal minor scrapes and burns, and even used as a shampoo to treat hair and scalp conditions (Siddhuraju et al., 2001). Some tribes believe that the seeds possess magical abilities to bring the owner good luck, the seeds would be strung together and used as jewelry. In the Philippines, a concoction from the whole plant, roots, bark, leaves and seeds is believed to treat the after effects of a stroke and improve blood flow to the brain (Cleversley, 2002).

Seeds are carminative, anodyne, spasmolytic bechic, anti-inflammatory, anathematic, antipatriotic, used in liver complaints, glandular swellings, debility, skin diseases (Wangchuk, et al., 2017). Tryptophan derivatives from the seed kernels of Entada rheedii Spreng. is antiproliferative of HIV and antioxidant (Nzowa et al., 2013). The juice of wood and bark is used for ulcers (Rajkumar \& Rajanna, 2011). Wangchuk et al. (2017) mentioned that the seeds are detoxifier and useful against liver poisoning, neuralgia, paralysis and other nerve related disorders. In India, the ground seeds are taken internally in contraception, snakebites and aphrodisiac. It is believed that the plant produces saponins, fatty oils and other potentially psychoactive alkaloids. One report (Cleversley, 2002) claims that the seeds contain as much as $18 \%$ essential oils, which may account for this plant's magical properties and its ability to help induce lucid dream states. In this context, the plant Entada rheedii Spreng. receives additional attentions of the researchers.

Unfortunately, deforestation of tropical forests in general and the overexploitation of the vines out of its multipurpose uses in specific caused rapid declination in its natural abundance. The vine shows poor natural regeneration from seeds due to delayed germination caused by extremely hard seed coat (up to $2 \mathrm{~mm}$ ) (Fig. 1) which is waxy, airtight and impermeable. Therefore, the sturdy seed coat ensures long dormant period without impairing the viability. In our observation, when seeds were sown in germination bed for germination trials, they remained viable for more than six months without germination or degradation of the quality. In natural condition inside the forests, the seeds usually germinate when the fruits are eaten by the elephants and seeds, that are partially digested with acidic and microbial actions inside the intestine, come out through feces. However, as elephant population is dwindling depending on them for natural regeneration is becoming less of an option and even if there is a small population of elephants they cannot be tapped for germination in large scale plantation programs. Despite some studies on the nutritional value, medicinal properties and uses in healthcare aspects of this plant, the information about the regeneration aspect of this valuable plant species is very scarce. Hence, to conserve this species besides harnessing its economic potential through plantations - it became essential to conduct research on regeneration, especially on the pre-sowing treatments for developing large number of propagule for plantation programs. Therefore, this research aimed to explore the germination potential and initial growth performance of seedlings of the hard coated Entada rheedii Spreng. seeds with various pre-sowing treatments and rooting ability of cuttings treated with different concentrations of exogenous rooting hormone (IBA) in two different seasons.

\section{Materials and methods}

The study was conducted at the nursery of Institute of Forestry and Environmental Sciences at Chittagong University campus. The nursery is located at $22^{\circ} 30^{\prime} \mathrm{N}$ and $91^{\circ} 50^{\prime} \mathrm{E}$ and enjoys typically tropical climate, characterized by hot humid summer and cool dry winter (Hossain et al., 2019). Mean monthly temperature varied from $26.2{ }^{\circ} \mathrm{C}$ to $32.5{ }^{\circ} \mathrm{C}$ maximum and $14.9{ }^{\circ} \mathrm{C}$ to $25.5^{\circ} \mathrm{C}$ minimum. Relative humidity is generally the highest (86\%) in June and lowest (59\%) in February to March. Mean annual rainfall of the area is about $916 \mathrm{~mm}$, which mostly takes place in June to October. Forest soils used in the nursery were moderately coarse to fine texture sandy with a $\mathrm{pH}$ 4.5. The study was involved with two different aspects: i) Pre-sowing treatments for seed germination to raise seedlings and ii) Clonal propagation by stem cutting.

\section{Seed germination and seedling raising}

\section{Fruit collection, seed extraction and pre-sowing treatments}

Ripe fruits of Entada rheedii Spreng. were collected in February and March from the reserve forests of Teknaf under Cox's Bazar South Forest Division. The fruits (pods) were measured for length, breadth, segments and thickness and dried up for two weeks for easy seed extraction. After extracting, the seeds were also measured for length, breadth and thickness 
including the seed coat and the cotyledon. Since germination percentage and seedling vigor was reported to be influenced by the seed size (Gunaga et al., 2007, 2011), uniform seeds (above average in size i.e., $4.5-4.8 \mathrm{~cm}$ length and $3.6-3.9 \mathrm{~cm}$ in breadth) were sorted out and used for the treatments to avoid the non-treatment variations. Around half of the seeds were cut with the hacksaw blade to make a small notch at the opposite sides of the embryo (Fig. 2) to facilitate moistening during germination. Rest of the seeds were kept intact. To determine the effects of the pre-sowing treatments on germination and seedling growth (i) both intact and cut seeds were soaked in water for $0 \mathrm{~h}, 24 \mathrm{~h}, 48 \mathrm{~h}$ and $72 \mathrm{~h}$. (ii) intact seeds were soaked in $5 \%$ (by volume) acetone solution for $5 \mathrm{~min}, 10 \mathrm{~min}$ and $20 \mathrm{~min}$. The treatments were designated as follows - intact seeds left without any treatment (soaked for $0 \mathrm{~h}$; I0) and soaked in water for 24 h (I1), 48 h (I2), 72 h (I3); cut seeds without any treatment (soaked for $0 \mathrm{~h}$; $\mathrm{C} 0$ ), soaked in water for $24 \mathrm{~h}(\mathrm{C} 1), 48 \mathrm{~h}$ (C2), 72h (C3), intact seeds soaked in $5 \%$ Acetone for $5 \mathrm{~min}$ (IA5), $10 \mathrm{~min}$ (IA10) and $20 \mathrm{~min}$ (IA20). Thirty seeds were sown in each replication and three replications formed a treatment.
Thus 90 seeds were subjected to each treatment and a total 990 seeds were sown under 11 treatments for the study.

\section{Seed sowing and data collection}

Seeds were sown in polybags filled with a 3:1 mixture of soil and decomposed cow-dung by dibbing them $0.5 \mathrm{~cm}$ into the mixture with thumb before covering up. Protective measures i.e., a shed made of local agro net of $5 \mathrm{~mm}$ mess was adopted against the hot sun, intensive rains, and birds and pesticide was used against the ants, insects, rodents and other pests. Watering and weeding were done regularly to ensure proper growth of seedlings. Loosening of topsoil was also done whenever the soils became compacted to prevent the growth of green mold on the soil surface.

Effects of pre-sowing treatments on E. rheedii seed germination was explored by counting the germinated seeds and assessing initial growth performance of seedlings. Germination initiated 14 days after sowing and culminated at 44 days. There was no new germination after 44 days and hence the germination percentage was determined after 44 days. The seedling
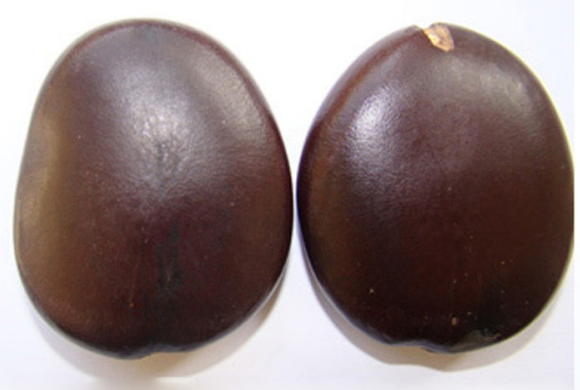

\section{A) Intact (Left) and cut (Right) seeds}

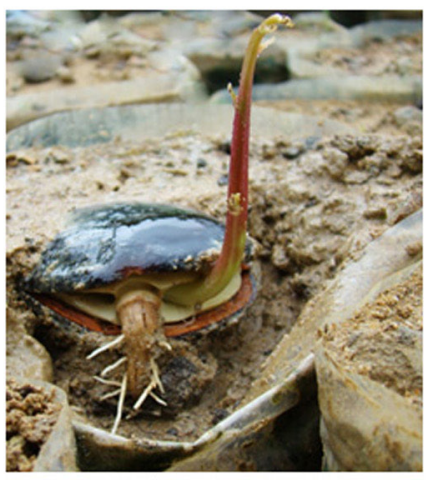

(F)

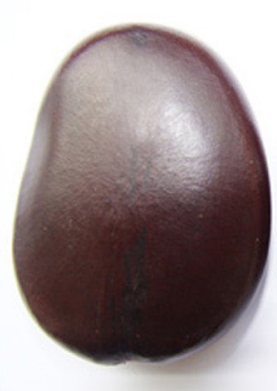
B) Intact (Left) and cut (Right)
seeds after $48 \mathrm{~h}$ soaking

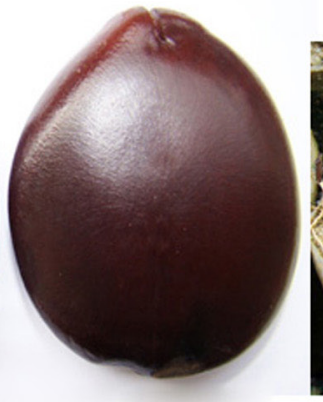

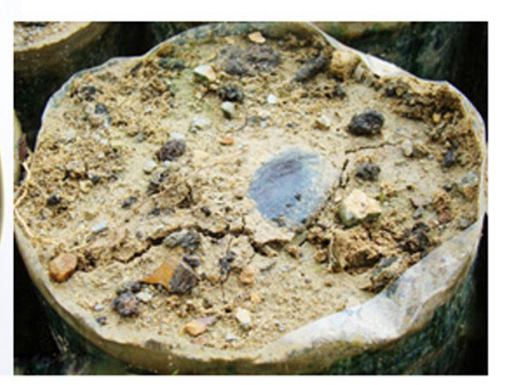

C) Sign of seed germination

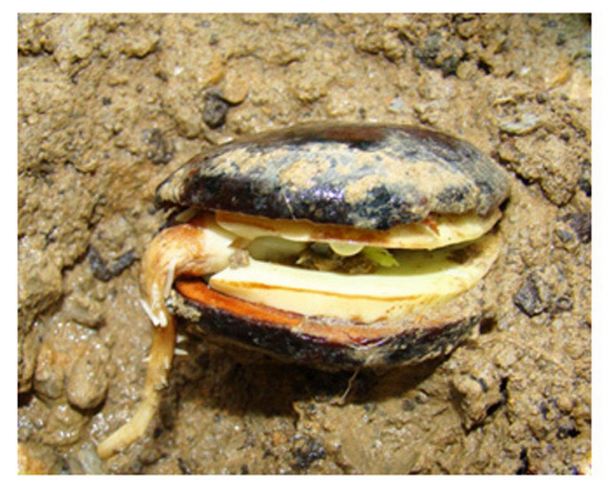

(E)

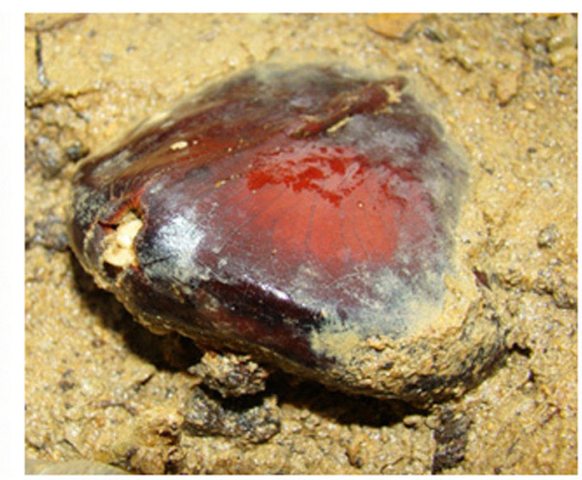

(D)

\section{Various stages of $E$. rheedii seed germination}

Fig. 2. Intact and cut seeds of E. rheedii (A), seeds after $48 \mathrm{~h}$ of soaking in water (B) and various stages of germination (C-F) 
height and collar diameter of all seedlings were recorded six months after sowing the seed to assess the growth performance of the E. rheedii seedlings. Growth performance was assessed by recording total length, root length, shoot length and leaf number of 10 random seedlings from each treatment by carefully uprooting them. Root, shoot and leaf components of the uprooted seeding were separated and dried in electric oven at $72{ }^{\circ} \mathrm{C}$ until reaching the constant weight and the dry weight of shoot, root and leaves were recorded.

\section{Clonal propagation through stem cutting}

Shoots were collected from 6 months (autumn cuttings) or 10 months (summer cuttings) old seedling (stockplants) raised in the nursery. One node cuttings with two leaves trimmed to half were prepared from the pre-selected E. rheedii stockplants for the experiment in June (summer cuttings) or in October (autumn cuttings). The lengths of summer and autumn cutting were $7.8-8.4 \mathrm{~cm}$ and $8.1-9.5$, respectively. The average diameter of summer and autumn cutting were $1.5-1.7 \mathrm{~mm}$ and $1.9-2.5 \mathrm{~mm}$, respectively. The lengths and diameters of cuttings were kept indifferent among the treatments to avoid the non-treatment variation.

The cuttings were briefly immersed into a fungicide solution - Diathene M45 (Rohm and Co. Ltd., France; $2 \mathrm{gm}$ per liter of water) to avoid fungal infection. Effect of IBA on rooting ability of cuttings was explored by dipping the base of the cuttings briefly (one minute) into $0 \%$ (TI0; control), $0.4 \%$ (TI1) and $0.8 \%$ (TI2) IBA solutions. IBA treated cuttings were then planted into perforated plastic trays filled with a mixture of coarse sand and fine gravels. The cuttings in the trays were then placed in completely randomized blocks into a non-mist propagator (Kamaluddin, 1996) for rooting.

\section{Rooting of stem cuttings}

A total of 180 cuttings were placed under three different treatments with three replications for each growing season in the non-mist propagator. Cuttings were planted in 18 trays, 6 trays for each treatment ( $0 \%, 0.4 \%$ and $0.8 \%$ IBA solution) and each tray containing 10 cuttings served as a plot. Thus the number of replicate cuttings per treatment was 60 . The cuttings were watered once only just after placing in the propagator followed by a light spray irrigation every morning with a hand spray till transferring the rooted cuttings from the propagator.

\section{Weaning and transferring the rooted cuttings into polybags \\ The cuttings were subjected to weaning before transferring them into polybags. Weaning was done}

to harden the rooted cuttings in prevailing adverse environment outside the propagator. It increases the survival capacity of the rooted cuttings. After weaning, all rooted cuttings were transferred into polybags filled with 3:1 soil and decomposed cow-dung. Before planting into the polybags, lengths and diameters of rooted cuttings were measured. Number of roots (all roots longer than $0.5 \mathrm{~cm}$ ) and the length of the longest root were measured and recorded for each cutting. After transferring into the polybags, the rooted cuttings were kept in shade for a week before placing them in the sun.

\section{Survival capacity of rooted cuttings}

Survival capacity indicates the survival potential of the rooted cuttings upon their transfer into the polybags in the nursery and allowing them to grow under direct sunlight for four months. The initial growth performance of all the rooted cuttings were assessed by measuring total height, collar diameter and leaf number four months of growing in the polybags in the nursery condition.

\section{Data analysis}

All data were analyzed in Microsoft Excel and IBM SPSS (ver.22). Analysis of Variances (ANOVA) and Duncan's Multiple Range Test (DMRT) was used to explore the possible treatment and seasonal variations in the cuttings. Percentages were adjusted following arcsine transformation formula before placing the data into analysis of variance (Zaman et al., 1983).

$$
\mathrm{Y}=\operatorname{Sin}^{-1} \mathrm{X}^{1 / 2}
$$

where:

- Y - Arcsine transformed value,

- X - proportion of number of cutting rooted to the number of cutting planted and the value 100 percent were substituted $(100-1 / 4 n)$ where ' $n$ ' is the number of units upon which the percentage data is based i.e., the denominator used in computing the percentages. Statistical significance in all analyses was determined at $p<0.05$.

\section{Results}

\section{Seed germination pattern}

Germination started with swelling of seeds followed by gradual splitting the seed coat and cotyledon with emergence of the radicle and the plumule (Fig. 2). The cut seeds soaked in water for $48 \mathrm{~h}$ (C2) showed the fastest germination (14 days after sowing) followed by the cut seeds soaked in water for 

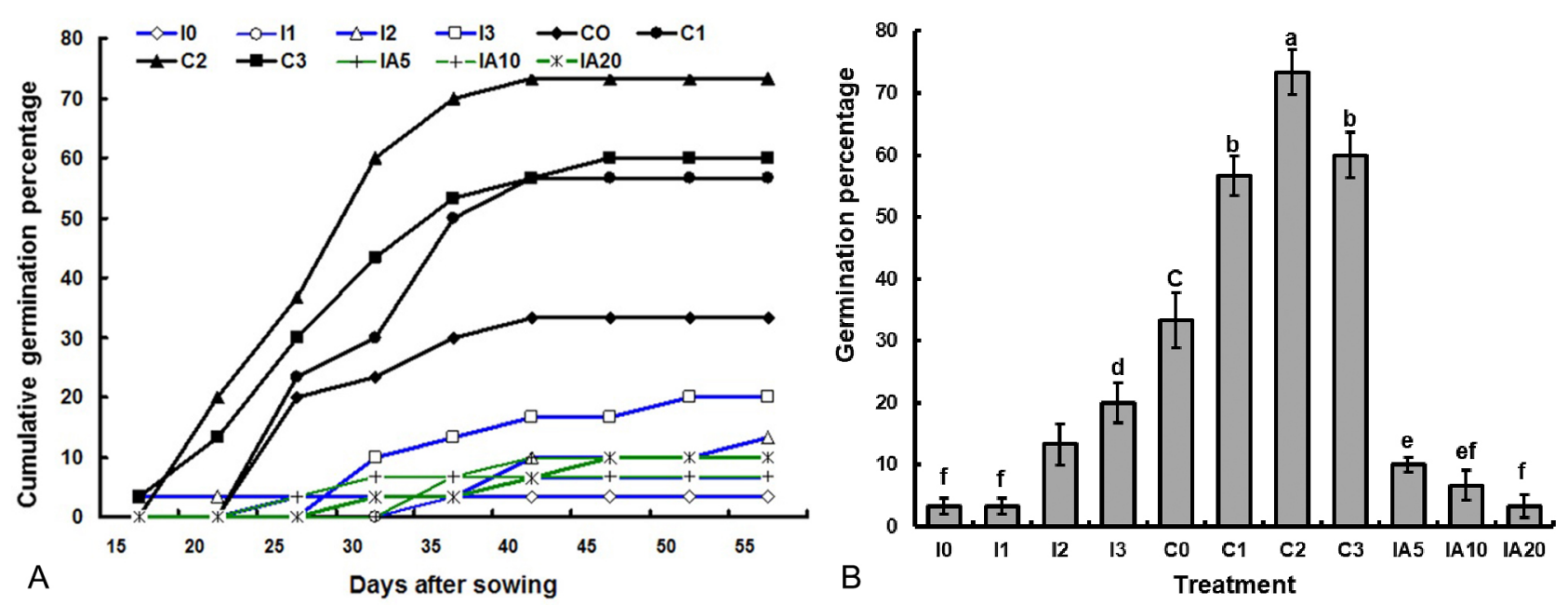

Fig. 3. Cumulative (A) and total (B) germination percentage of E. rheedii seeds treated with various pre-sowing treatments. Intact seeds without any treatment (I0), intact seeds soaked in water for $24 \mathrm{~h}$ (I1), $48 \mathrm{~h}$ (I2), $72 \mathrm{~h}$ (I3); cut seeds without any treatment (C0), cut seeds soaked in water for $24 \mathrm{~h}(\mathrm{C} 1), 48 \mathrm{~h}(\mathrm{C} 2), 72 \mathrm{~h}(\mathrm{C} 3)$; intact seeds soaked in 5\% Acetone for 5 minute (IA5), 10 minute (IA10) and 20 minute (IA20). Percentages were adjusted using arcsine transformation formula before placing the data into analysis of variance. The same letters on the bars indicate no significant difference at $\mathrm{p}<0.05$ according to Duncan's Multiple Range Test (DMRT). Error bar (I) indicates the standard error of means

$72 \mathrm{~h}$ while intact seeds without treatment showed the slowest germination (30 days after sowing). Interestingly, most of the intact seeds remained ungerminated yet completely viable even two month after sowing then in germination media (supplemental Fig. S1) due to thick, waxy, airtight and impermeable seed coats that prevented water penetration for seed germination. Accordingly, seeds of E. rheedii may remain viable for years without germinating. The cumulative germination percentage for $\mathrm{C} 2$ reached from $15 \%$ on day 15 to its peak $73 \%$ on day 44 after sowing and remained constant henceforth till the end of germination test ( 60 days). On the other hand, the cumulative germination percentage for $\mathrm{C} 3$ reached from $10 \%$ on day 15 to its peak $60 \%$ on day 40 after sowing and remained constant up to the end of the germination period (60 days). Germination started

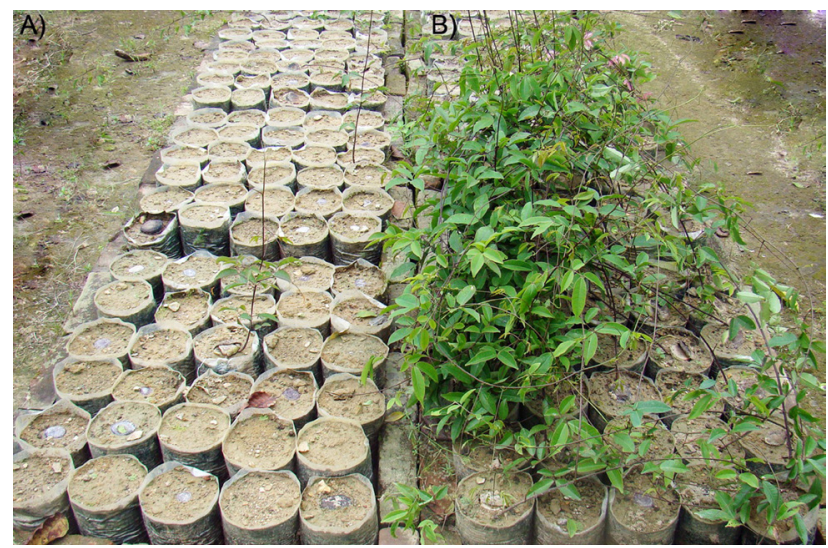

Fig. 4. Germination pattern of intact (A) and cut (B) seeds of $E$. rheedii in the nursery beds four months after sowing the seeds in treatments I0, I1, C0 and IA20 on day 25, 35, 25 and 30 , respectively and ended on day 55 with very low cumulative germination percentages. Treatment IA5 showed slightly better germination percentage though germination started on day 35 (Fig. 3).

\section{Germination percentage}

The range of germination percentages among the treatments of E. rheedii seeds was 3.3 to 73.3. Cut seeds soaked in water for $48 \mathrm{~h}$ (C2) showed the highest germination percentage (73.3) followed by cut seeds treated with water for $72 \mathrm{~h}(60 \%)$ while intact seeds without any treatment or seeds treated with $5 \%$ acetone for $20 \mathrm{~min}$ (3.3\%) exhibited the lowest germination percentage (Fig. 3 and Fig. 4).

\section{Seedling growth performance}

The average height of $E$. rheedii seedlings varied significantly $(p<0.001)$ among seeds with different pre-sowing treatments six months after sowing the seeds. As shown in figures 5 and 6 , the maximum height growth was for treatment C2 $(153.3 \mathrm{~cm})$ followed by C3 $(131.7 \mathrm{~cm})$ IA5 $(116.7 \mathrm{~cm})$ and the lowest was in I1 $(87 \mathrm{~cm})$ six months after sowing the seeds. Collar diameter of seedlings varied from 3.4 $\mathrm{mm}$ to $5.5 \mathrm{~mm}$ among treatments six months after sowing the seeds. The highest collar diameter was recorded for C2 $(5.5 \mathrm{~mm})$ followed by IA10 $(5 \mathrm{~mm})$ and the minimum was for I0 $(3.43 \mathrm{~mm})$. The average number of leaves in seedling also varied significantly $(p<0.01)$ among the treatments. The maximum number of leaves was observed for C2 (14.3) 
followed by C3 and the lowest was for IA5 (8.67) (Fig. 5 and Fig. 6).

Average dry weight of shoots, leaves and roots as well as total dry weight of E. rheedii seedling grown from seeds under different pre-sowing treatments significantly $(p<0.01)$ varied. The highest shoot weight and leaf dry weight was noticed for C2 followed by $\mathrm{C} 3$ and the lowest was in $\mathrm{C} 0$. However, maximum root dry weight was for $\mathrm{C} 0$ followed by $\mathrm{C} 3$ and the lowest was in $\mathrm{C} 1$. The range of dry weight for seedlings was $3.6 \mathrm{~g}$ to $5.7 \mathrm{~g}$ six months after sowing the seeds. Maximum plant dry weight was for $\mathrm{C} 2$ $(5.7 \mathrm{~g})$, followed by C3 (5.47 g) and the lowest was for I0 $(3.6 \mathrm{~g})$. The average dry weight of seedlings grown from cut seeds was higher than those from the intact seeds.

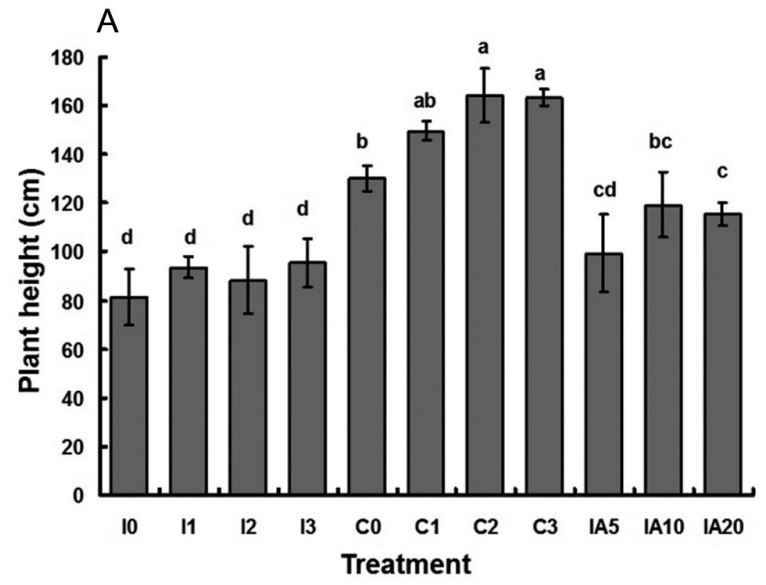

\section{B}

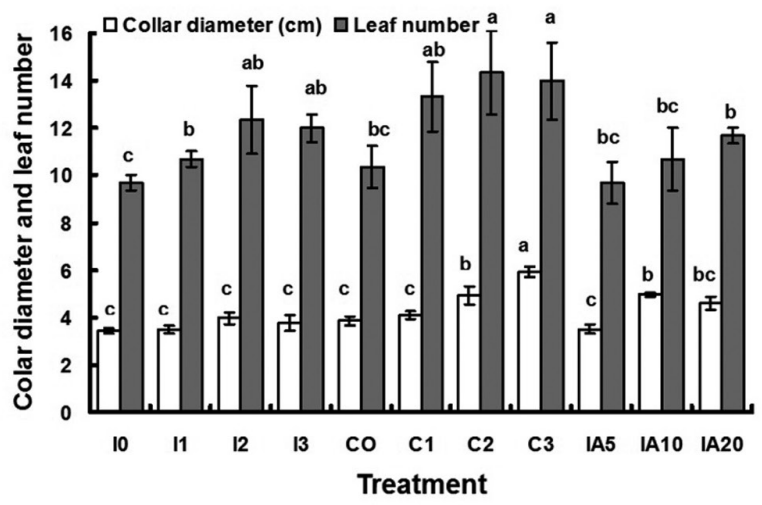

Fig. 5. Plant height growth (A), collar diameter and leaf number (B) of seedlings germinated under different pre-sowing treatment six months after sowing the seeds. Intact seeds without any treatment (I0), intact seeds soaked in water for $24 \mathrm{~h}$ (I1), $48 \mathrm{~h}$ (I2), $72 \mathrm{~h}$ (I3); cut seeds without any treatment (C0), cut seeds soaked in water for $24 \mathrm{~h} \mathrm{(C1),} 48$ $\mathrm{h}$ (C2), 72h (C3); intact seeds soaked in 5\% Acetone for $5 \mathrm{~min}$ (IA5), $10 \mathrm{~min}$ (IA10) and $20 \mathrm{~min}$ (IA20). The same letters on the bars indicate no significant difference at $p<0.05$ according to Duncan's Multiple Range Test (DMRT). Error bar (I) indicates the standard error of means
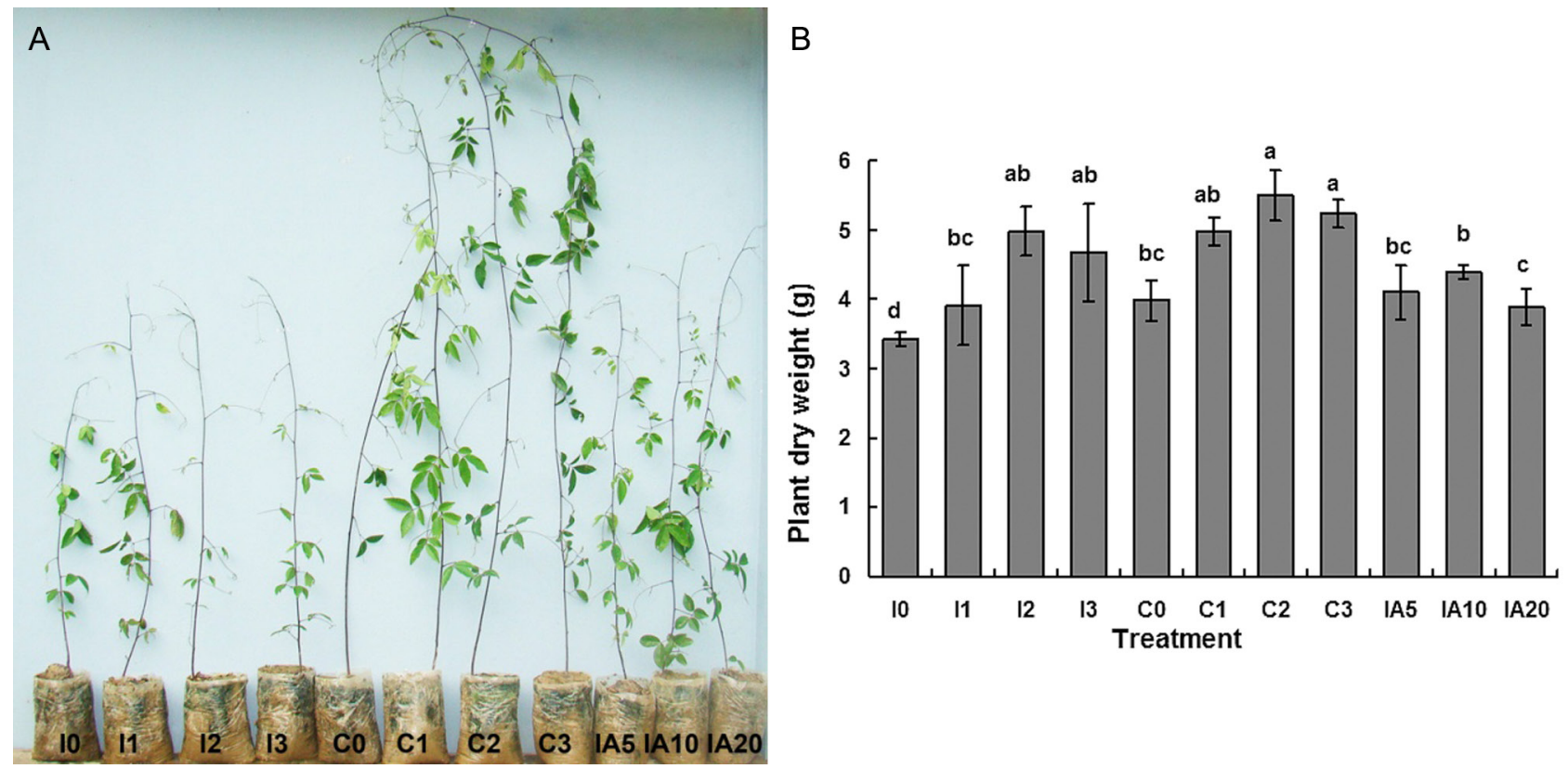

Fig. 6. Height growth performance (A) and plant dry weight (B) of E. rheedii seedlings grown from seeds with various pre-sowing treatments six months after sowing the seeds. Intact seeds without any treatment (I0), intact seeds soaked in water for $24 \mathrm{~h}$ (I1), $48 \mathrm{~h}$ (I2), $72 \mathrm{~h}$ (I3); cut seeds without any treatment (C0), cut seeds soaked in water for $24 \mathrm{~h}$ (C1), $48 \mathrm{~h} \mathrm{(C2),} 72 \mathrm{~h}$ (C3); intact seeds soaked in 5\% Acetone for $5 \mathrm{~min}$ (IA5), $10 \mathrm{~min}$ (IA10) and $20 \mathrm{~min}$ (IA20). The same letters on the bars indicate no significant difference at $p<0.05$ according to ANOVA and DMRT. Error bar (I) indicates the standard error of means 


\section{Clonal propagation through stem cutting}

\section{Rooting ability of Entada rheedii Spreng. stem cutting}

Rooting percentage of E. rheedii stem cuttings ranged 54.3 to 66.7 and 57.3 to 64.6 respectively for summer and autumn cuttings among the treatments (Fig. 7). Variation in rooting percentage was insensitive to the exogenous application of rooting hormone (IBA). In the summer cuttings, the highest rooting percentage was for $0.8 \%$ IBA treatment $(66.7 \%)$ while in autumn cuttings it was for $0.4 \%$ IBA treatment $(64.6 \%)$. The lowest rooting
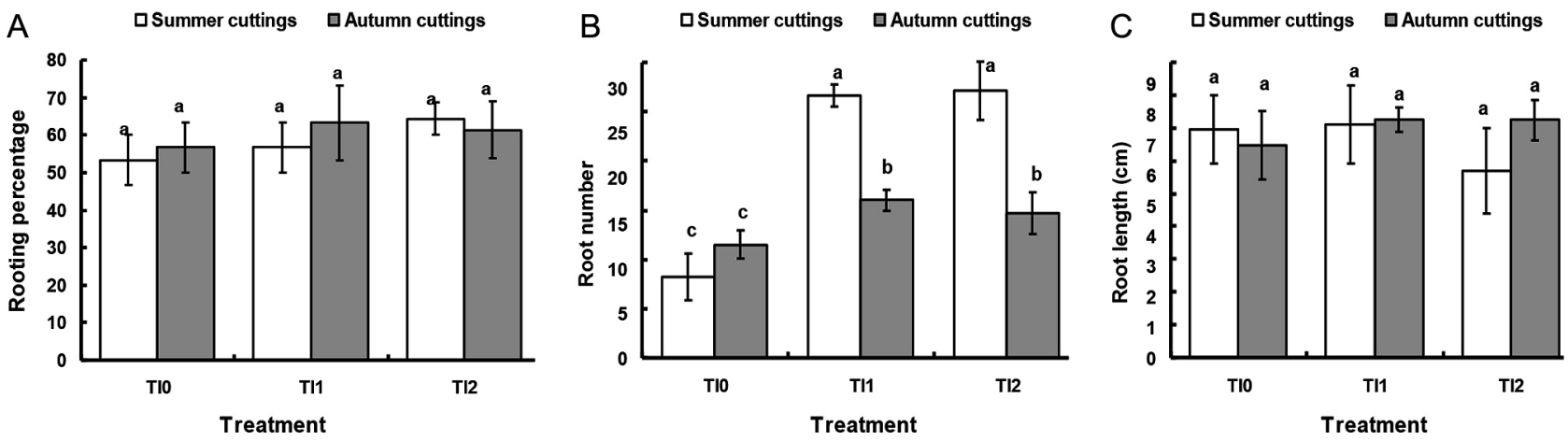

Fig. 7. Rooting percentage (A), root number (B) and root length (C) of E. rheedii stem cuttings treated with $0 \%$ (TI0), $0.4 \%$ (TI1) and $0.8 \%$ (TI2) IBA solution four weeks after placing the cuttings in the rooting media. Percentages were adjusted using arcsine transformation formula before placing the data into analysis of variance. The same letters on the bars indicate no significant difference at $p<0.05$ according to ANOVA and DMRT. Error bar (I) indicates the standard error of means
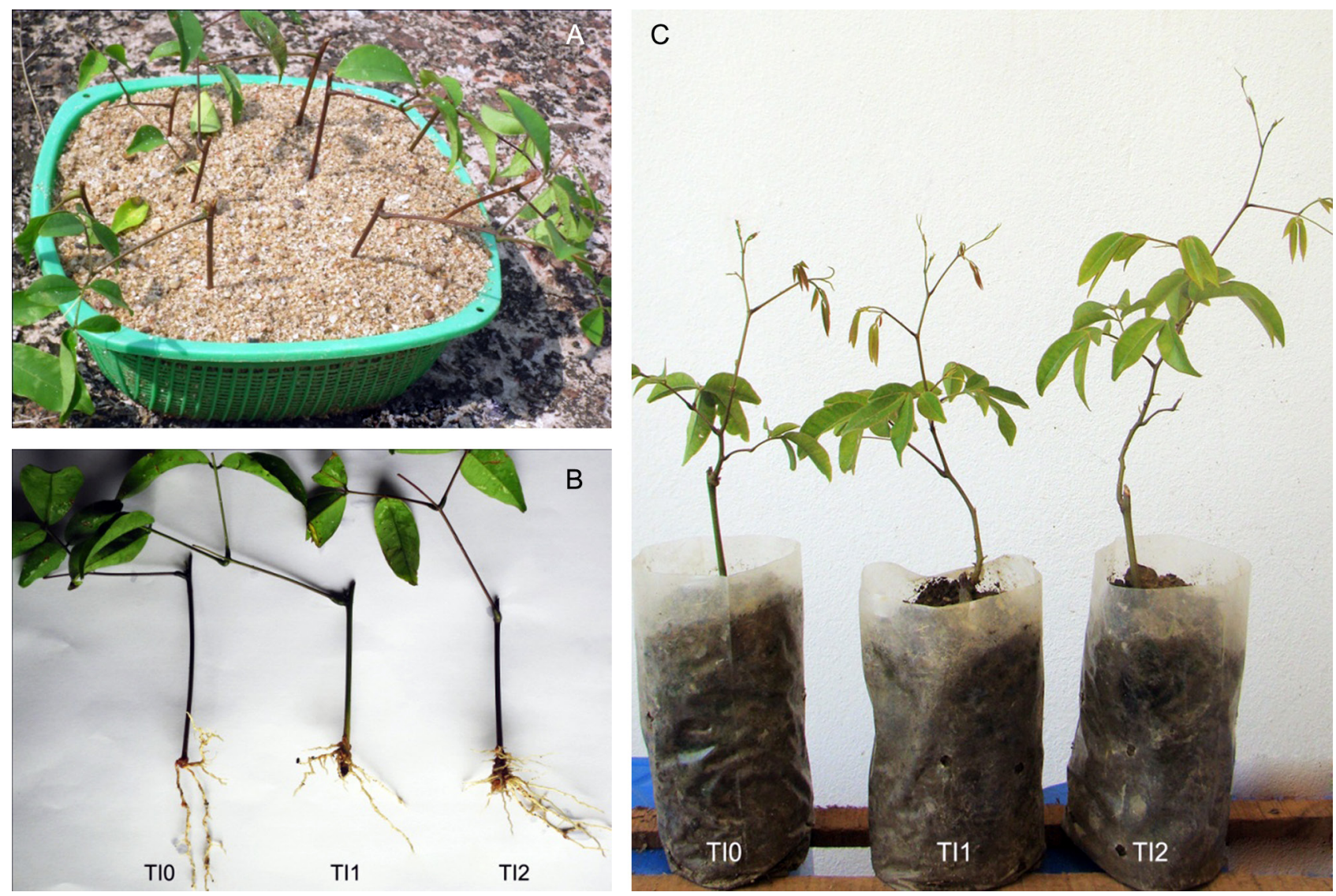

Fig. 8. Rooting ability and steckling capacity of E. rheedii cuttings. A) Cuttings rooted in the perforated plastic tray filled with coarse sands, B) cuttings rooted with $0 \%$ (TI0), $0.4 \%$ (TI1) and $0.8 \%$ (TI2) IBA solution and C) initial growth performance of representative summer cuttings rooted with different concentrations of IBA solution three months after transferring the rooted cuttings in the polybags 
percentages $(54.3 \%$ and $57.3 \%$ respectively in summer and autumn cuttings) was observed in control (TI0). However, significant differences have been observed in root number among the cutting types and treatments applied. Average number of roots in summer cuttings varied from 8.3 to 36.6 among the treatments. The highest number of root (36.6) was for cuttings treated with $0.4 \%$ IBA solution followed by 27.1 in $0.8 \%$ IBA and the lowest was in TIO (control cuttings). However, the highest number of root per cutting in autumn was 16.1 when treated with $0.8 \%$ IBA solution followed by TI1 (cutting treated with $0.4 \%$ IBA solution) and the lowest (11.5) was noticed in TIO (Fig. 7 and Fig. 8). Mean length of longest roots of summer and autumn cuttings varied respectively between $5.9 \mathrm{~cm}$ and $9.1 \mathrm{~cm}$ and $6.5 \mathrm{~cm}$ and $8.0 \mathrm{~cm}$. The longest root $(9.1 \mathrm{~cm})$ was for the summer cuttings with $0.4 \%$ IBA treatment followed by the control and the shortest was for $0.8 \%$ IBA treatment. In autumn cutting, the longest root was $6.5 \mathrm{~cm}$ for cuttings treated with $0.8 \%$ IBA followed by $0.4 \%$ IBA and the shortest $(5.9 \mathrm{~cm})$ was in control. No significant difference was noticed in root length among the treatments applied or the cutting types (Fig. 7 and Fig. 8).

\section{Survival and growth performance of summer rooted cuttings}

Three months after transferring into polybags, the survival percentage of rooted cuttings ranged from 53 to 69 across the treatments - the highest being for the cuttings rooted with $0.4 \%$ IBA solution (69\%) followed by $0.8 \%$ IBA $(58.3 \%$ ) and the lowest $(53 \%)$ in control. The height attained by rooted cuttings three months after planting in the polybag ranged from $17.9 \mathrm{~cm}$ to $29.6 \mathrm{~cm}$ among the treatments with significant enhancement of height due to the application of IBA (Fig. 8c and Table 1). The maximum height growth was in cuttings rooted with $0.8 \%$ IBA $(29.6 \mathrm{~cm})$ followed by those treated with $0.4 \%$ IBA $(19.1 \mathrm{~cm})$ while the lowest was in control $(17.9 \mathrm{~cm})$. However, the mean leaf number of rooted cuttings was insensitive to IBA treatment (Table 1).

Table 1. Effect of IBA concentration on height and leaf number of $E$. rheedii rooted cuttings three months after transferring the rooted cuttings in the polybags

\begin{tabular}{lrrrr}
\hline \multirow{2}{*}{\multicolumn{1}{c}{ Variable }} & \multicolumn{3}{c}{ Treatments } & \multirow{2}{*}{ p } \\
\cline { 2 - 4 } & \multicolumn{1}{c}{ TI0 } & \multicolumn{1}{c}{ TI1 } & TI2 & \\
\hline Survival percentage & $52.9 \pm 5.2^{\mathrm{b}}$ & $68.8 \pm 6.5^{\mathrm{a}}$ & $58.3 \pm 0.9^{\mathrm{ab}}$ & 0.002 \\
Height $(\mathrm{cm})$ & $17.9 \pm 0.9^{\mathrm{b}}$ & $19.6 \pm 0.8^{\mathrm{b}}$ & $29.1 \pm 1.0^{\mathrm{a}}$ & 0.047 \\
Leaf number & $7.0 \pm 1.5^{\mathrm{a}}$ & $7.6 \pm 0.9^{\mathrm{a}}$ & $9.4 \pm 0.6^{\mathrm{a}}$ & 0.109 \\
\hline
\end{tabular}

The same superscript letters indicate no significant difference at $p<0.05$ according to ANOVA and DMRT). Percentages were adjusted using arcsine transformation formula before placing the data into analysis of variance. \pm indicates the standard error of means.

\section{Discussion}

\section{Germination performance}

The fastest germination with highest germination percentage was recorded from the cut seeds soaked in water for $48 \mathrm{~h}(\mathrm{C} 2)$ followed by the cut seeds soaked in water for $72 \mathrm{~h}$ (C3) while intact seeds without treatment showed the slowest and minimum (3\%) germination (Fig. 3 and Fig. 4). The cumulative germination percentage for $\mathrm{C} 2$ soared to its peak $(73 \%)$ 44 days after sowing followed by C3 (60\%) which reached on day 40 of sowing and remained constant up to the end of the germination period (60 days) (Fig. 3). The seeds of most of the Fabaceae species have been observed to exhibit physical dormancy due to presence of hard seed-coat and thereby resulted poor seed germination (Azad et al., 2006). Therefore several methods are being applied for breaking the dormancy and enhancing the germination potentials of the Fabaceae seeds. Some commonly used methods to overcome physical dormancy of seeds are acid scarification, mechanical scarification and immersion in water (Baskin and Baskin, 2004). Immersion in hot water and subsequently soaked in cold water was reported to enhance germination percentage of Albizia procera (Azad et al., 2012) and A. lebbeck (L.) Benth (Kumar et al., 2018). Scarification by mechanically nicking with secateurs resulted $100 \%$ germination in Acacia polyacantha with maximum seedling growth (Missanjo et al., 2014). Nail clipping in one side of the seed (at the distal end of the seed) and soaking in water provided the highest seed germination was reported by Alamgir and Hossain (2005). The results of the present study were also in line with the observations from Hossain et al. (2005a, 2005b) as they reported the highest germination percentages for hard-coated seeds of Terminalia belerica and T. chebula $(88.9 \%$ and $66.7 \%$, respectively) in depulped seeds soaked in water for $48 \mathrm{~h}$ followed by the depulped seeds soaked in water for $24 \mathrm{~h}$ and the lowest germination percentage $(58.9 \%)$ in control i.e., intact seeds without soaking in water. Nongrum and Kharlukhi (2013) also reported significantly higher germination percentage of Abizia chinensis seeds (96.66\%) soaked in water after nicking. Similar results were reported by Hossain et al. (2011) who recorded highest cumulative germination percentage in $F$. jangomas seeds soaked in water for $48 \mathrm{~h}$ followed by seeds soaked in water for $24 \mathrm{~h}$. Ara et al. (1997) reported 70-75\% germination in $T$. belerica seeds soaked in water for $48 \mathrm{~h}$ followed by depulped fruits. Also, Hossain et al. $(2013,2014 a)$ reported the highest germination percentage in depulped seeds soaked in water for 48 $\mathrm{h}$ for both the species T. belerica (93\%) and T. chebula (73.3\%). Generally, the legume seeds with hard seed coats show enhanced germination with pre-sowing 
treatments (Alamgir \& Hossain, 2005; Azad et al., 2011, 2012; Nongrum \& Kharlukhi, 2013; Missanjo et al., 2014). Entada rheedii Spreng. seeds were also treated with acetone for 5 minutes, 10 minutes and 20 minutes. The reason behind treating the seeds with acetone was that in our preliminary study, we noticed seeds were impermeable but after making small notch they became permeable and germinated. We then thought that one of the reasons of this impermeability was the wax i.e., the seed coat was covered with thin layer of wax. Wax on the seed coat might be dissolved in acetone and enhance the germination of the seeds by decreasing physical dormancy (Subbaiah, 1982). However, germination percentage of $E$. rheedii in this study was not enhanced significantly with acetone treatment as we can see in Figure 3 and Figure 4. Moreover the result of acetone treatment on seed germination was non-specific. The reasons behind decreasing the germination percentage of $E$. rheedii seeds when treated with acetone could not be justified due to lake of relevant literature.

\section{Seedling growth performance}

The average height of $E$. rheedii seedlings was maximum for treatment $\mathrm{C} 2(153.3 \mathrm{~cm})$ followed by C3 $(131.7 \mathrm{~cm})$ IA5 $(116.7 \mathrm{~cm})$ and the lowest was in I1 $(87 \mathrm{~cm})$ six months after sowing the seeds (Fig. 5 and Fig. 6). The highest collar diameter was also recorded for C2 $(5.5 \mathrm{~mm})$ followed by IA10 $(5 \mathrm{~mm})$ and the minimum was for I0 $(3.43 \mathrm{~mm})$. Although, the maximum number of leaves was observed for C2 (14.3) followed by C3 and the lowest was for IA5 (8.67). Missanjo et al. (2014) reported $100 \%$ germination in Acacia polyacantha with maximum seedling height, colar diameter and leaf number scarification by nicking with secateurs. Hossain et al. (2005a, 2005b) and Hossain et al. (2013, 2014a) reported maximum height growth of $T$. belerica and T. chebula seedlings for seeds soaked in water for $48-72 \mathrm{~h}$ and the lowest in controlled seeds. Significantly higher collar diameter in the $T$. chebula seedlings treated with $72 \mathrm{~h}$ soaking in cold water compared to other treatments was reported by Hossain et al. (2005b). However, Hossain et al. (2005a) for T. belerica and Hossain et al. (2014a) for T. belerica and T. chebula seedlings did not find any significant difference in collar diameter among treatments. Regarding the maximum number of leaves, the observations in this study were supported by the reports from Hossain et al. (2005a) for T. belerica, Hossain et al. (2005b) for T. chebula and Hossain et al. (2013, 2014a) for both T. belerica and T. chebula.

\section{Biomass production}

Average dry weight of shoots, leaves and roots as well as the total dry weight of $E$. rheedii seedling were significantly $(p<0.01)$ enhanced due to the different pre-sowing treatments. The highest shoot weight and leaf dry weight was noticed for $\mathrm{C} 2$ followed by C3 and the lowest was in I0. Dry weight of seedlings grown from cut seeds was higher than those from the intact seeds. The findings of the present study regarding the shoot and leaf dry weight of seedlings were supported by Hossain et al. (2005a, 2005b) as they observed maximum shoot and leaf dry weights for $T$. belerica and $T$. chebula seedlings grown from seeds soaked in water for $48 \mathrm{~h}$. Besides these, Nongrum and Kharlukhi (2013) reported highest seedling dry weight of Abizia chinensis seeds germinated by soaking the seeds in water after nicking. Nail clipping in one side of the seed (at the distal end of the seed) and soaking in water provided the highest seed germination and seedling dry weight was reported by Alamgir and Hossain (2005). Again, Hossain et al. (2005a, 2005b, 2013, 2014a,) demonstrated significantly higher shoot, root and leaf dry weight for T. chebula seedlings grown from seeds soaked in water for $48 \mathrm{~h}$ compared to seedlings from other treatments. The results regarding the total dry mass of seedlings also conformed to Hossain et al. (2005a, 2005b).

\section{Rooting ability of $E$. rheedii stem cutting}

The rooting percentage of $E$. rheedii stem cuttings ranged 54.3 to 66.7 and 57.3 to 64.6 for summer and autumn cuttings respectively (Fig. 7) which was insensitive to the exogenous application of rooting hormone (IBA) and the cutting types. The highest rooting percentage was for $0.8 \%$ IBA treatment $(66.7 \%)$ in summer cuttings and for $0.4 \%$ IBA treatment $(64.6 \%)$ in autumn cuttings while the lowest rooting percentages was in control (TI0). Significant difference was noticed in root number but indifference in average length of roots developed in the cuttings among the cutting types and treatments applied (Fig. 7). The highest number of root per cutting (36.6) was for $0.4 \%$ IBA treatment followed by $0.8 \%$ IBA (27.1) in summer cuttings and 16.1 with $0.8 \%$ IBA solution followed by 14.2 with $0.4 \%$ IBA solution in the autumn cuttings while the lowest was in TIO (control cuttings) in both the seasons (Fig. 7 and Fig. 8). Applied rooting hormone IBA is known to intensify the rooting ability of cuttings explained by several authors. For instance, Hossain et al. (2014b) reported the highest rooting percentages $(63 \%)$ and maximum number of root (4.8) per cutting when single node cuttings of Anisoptera scaphula stem were treated with $0.8 \%$ IBA solution followed by $0.4 \%$ IBA and the lowest was in control. Similar result was reported by Hossain et al. (2019) for Podocarpus neriifolius D. Don. where highest rooting percentage (61.3) was recorded from $0.8 \%$ IBA treated cuttings. 
In a separate experiment, Hossain et al. (2002, 2011) observed rooting enhancement in Artocarpus heterophyllus and Flacourtia jangomas stem cuttings with IBA treatment. Similar observations were made by Abdullah et al. (2005) for Baccaurea sapida, Baul et al. (2009) for Stereospermum suaveolens, Baul et al. (2011) for Litsea monopetala, Dias et al. (1999) for Platanus acerifolia, Rosa (1997) for Tachi-branco (Sclerolobium paniculatum), Kamaluddin and Ali (1996) for A. heterophyllus and Kamaluddin et al. (1998) for C. velutina. No significant difference was noticed in root length among the treatments applied or the cutting types (Fig. 7 and Fig. 8). However, the longest root was reported for P. neriifolius (Hossain et al., 2019) and B. sapida Muell. (Abdullah et al., 2005) cuttings treated with $0.4 \%$ IBA treatment followed by $0.8 \%$ IBA and the lowest was in controlled cuttings. Baul et al. (2009) showed that cuttings treated with $0.2 \%$ IBA produced longest roots in Stereospermum suaveolens tem cuttings.

Actually the required concentration of exogenous IBA for rooting varied based on species, nature (woody or soft cuttings) and state of the cuttings. The doses ranged from $0.1 \%$ (Baul et al., 2011) to $10.0 \%$ (Lee \& Bilderback, 1990). However, in most of the cases researchers noticed significantly higher rooting percentage with $0.4 \%$ IBA solution. For examples, Hossain et al. $(2002,2004)$ reported significantly enhanced rooting percentage in the cuttings of Artocarpus heterophyllus, Swietenia macrophylla and Chukrasia velutina, respectively with $0.4 \%$ IBA solution. Tchoundjeu et al. (2004) obtained better rooting percentage with $0.4 \%$ IBA treatment in $P$. johimbe, and Abdullah et al. (2005) in B. sapida cuttings. Again, Baul et al. (2009) stated better rooting performance in S. suaveolens cuttings with $0.4 \%$ IBA solution. Negash (2002) noticed suggestively decreased rooting percentage and root number in Juniperus procera when they were treated with $0.4 \%$ IBA concentration.

\section{Survival of E. rheedii rooted cuttings}

The survival percentage of rooted cuttings three months after transferring them into polybags, ranged from 53 to 69 across the treatments. The highest being for the cuttings rooted with $0.4 \%$ IBA solution (69\%) followed by $0.8 \%$ IBA (58) and the lowest (53\%) in control. The maximum height growth was in cuttings rooted with $0.8 \%$ IBA $(29.6 \mathrm{~cm})$ followed by those treated with $0.4 \%$ IBA $(19.1 \mathrm{~cm})$ while the lowest was in control $(17.9 \mathrm{~cm})$. However, the mean leaf number of rooted cuttings was insensitive to IBA treatment (Table 1). This was in accordance with the reports from Hossain et al. (2014b, 2019) as they found significantly higher survival of rooted cuttings for $A$. scaphula and $P$. neriifolius in nursery with IBA treatment over control. Also, Hossain et al. (2011) obtained the highest (85\%) survival in the $F$. jangomas cuttings treated with $0.4 \%$ IBA and the lowest in control. The higher number of roots per cutting due to IBA treatment may be the cause of better survival and growth of rooted cuttings in the nursery condition. However, Baul et al. (2009) reported reduced survival percentage in rooted cuttings treated with higher IBA concentrations.

\section{Conclusion}

Dormancy and thick hard seed coat inhibits easy germination of seeds of many tropical indigenous plant species. Therefore, species specific optimized treatment of seeds becomes inevitable to enhance the production of vigorous seedlings at minimum cost; time and labor. In this study, germination performance (germination percentage, cumulative germination percentage over time), initial seedling growth performance (height, collar diameter and leaf number), and biomass yield (in terms of shoot dry weight, leaf dry weight and total dry weight) was assessed for different seed treatments for hard seed coated species $E$. rheedii. The best treatment was cut seeds soaking in water for $48 \mathrm{~h}$ (C2). Besides, the clonal propagation from autumn and summer cuttings for the species was studied under different IBA treatments. In both the seasons, the species was amenable to clonal propagation through stem cutting even without any rooting hormone IBA $(57.6 \%$ and $54.7 \%$ in autumn or summer cutting treated respectively). However, the best result in terms of rooting percentage, root number and steckling capacity, the cuttings treated with $0.4 \%$ IBA solution was recommended by this research.

\section{Acknowledgement}

Authors gratefully acknowledge the contribution of Professor Dr. Mohammad Mosharraf Hossain for language checking and editing services and four anonymous reviewers for their critical review and suggestions for improving the manuscripts.

\section{Reference}

Abdullah ATM, Hossain MA \& Bhuiyan MK (2005) Propagation of Latkan (Baccaurea sapida Muell. Arg) by mature stem cutting. Research Journal of Biological Sciences 1: 129-134.

Alamgir M \& Hossain MK (2005) Effect of pre-sowing treatments on germination and initial seedling development of Albizia saman in the nursery. Journal of Forestry Research 16: 200-204. doi:10.1007/BF02856814. 
Ara R, Merry SR \& Siddiqi NA (1997) Cultivation and uses of twelve medicinal plants of Bangladesh. Bulletin7, Minor Forest Products Series, Bangladesh Forest Research Institute, Chittagong, pp. 27-31.

Awale P (2005) Sea Bean. http://www.flowersofindia.net/catalog/slides/Sea\%20Bean.html.

Azad MS, Biswas RK \& Matin MA (2012) Seed germination of Albizia procera (Roxb.) Benth. in Bangladesh: a basis for seed source variation and pre-sowing treatment effect. Forestry Studies in China 14: 124-130. doi:10.1007/s11632-0120209-z.

Azad S, Manik MR, Hasan MS \& Matin MA (2011) Effect of different pre-sowing treatments on seed germination percentage and growth performance of Acacia auriculiformis. Journal of Forestry Research 22: e183. doi:10.1007/s11676-011-0147-y.

Azad MS, Islam MW, Matin MA \& Bari MA (2006) Effect of pre-sowing treatment on seed germination of Albizia lebbeck (L.) Benth. South Asian Journal of Agriculture 1: 32-34.

Banerjee R \& Dixit BS (1998) Potential under exploited minor oilseeds resources for oil-based industries. Applied Botanical Abstracts 18: 134150.

Baskin JM \& Baskin CC (2004) A classification system for seed dormancy. Seed Science Research. 14: 1-16.

Baul TK, Hossain MM, Mezbahuddin M \& Mohiuddin M (2011) Vegetative propagation of Litsea monopetala, a wild tropical medicinal plant: Effects of indole-3-butyric acid (IBA) on stem cuttings. Journal of Forestry Research 22: 409-416. doi:10.1007/s11676-011-0111-x.

Baul TK, Mezbahuddin M \& Mohiuddin M (2009) Vegetative propagation and initial growth performance of Stereospermum suaveolens DC., a wild tropical tree species of medicinal value. New Forests 37: 275-283. doi:10.1007/s11056-008-9123-6.

Cleversley K (2002) Entada rheedii - African dream herb. http://entheology.com/plants/entada-rheedii-african-dream-herb/.

Dias RMSL, Fronco ETH \& Dias CA (1999) Rooting of stem cuttings of different diameters of Platanus acerifolia (Aiton) Willdenow. Ciencia Florestal 9: 127-136.

Gunaga RP, Doddabasava \& Vasudeva R (2011) Influence of seed size on germination and seedling growth in Mammea suriga. Karnataka Journal of Agricultural Sciences 24: 415-416.

Gunaga RP, Hareesh TS \& Vasudeva R (2007) Effect of fruit size on early seedling vigour and biomass in white Dammer (Vateria indica): A Vulnerable and economically Important Tree Species of the Western Ghats. Journal of NTFPs 14: 197-200.
Hossain MA, Islam MA, Azad MAK, Rahman MM, Shumi W \& Shukor NAA (2019) Propagation of an endangered gymnosperm tree species (Podocarpus neriifolius D. Don.) by stem cuttings in nonmist propagator. Pertanika Journal of Tropical Agricultural Sciences 42: 237-250.

Hossain MA, Uddin MS, Shumi W \& Shukor NAA (2014a) Depulping of fruits and soaking the seeds enhances the seed germination and initial growth performance of Terminalia belerica Roxb seedlings. American Journal of Plant Sciences 5: 714-725. doi:10.4236/ajps.2014.55086.

Hossain MA, Ferdous J, Rahman MA, Azad MAK \& Shukor NAA (2014b) Towards the propagation of a critically endangered tree species Anisoptera scaphula. Dendrobiology 71: 137-148. doi:10.12657/ denbio.071.014.

Hossain MA, Uddin MS, Rahman MM \& Shukor NAA (2013) Enhancing seed germination and seedling growth attributes of a medicinal tree species Terminalia chebula through depulping of fruits and soaking the seeds in water. Journal of Food Agriculture and Environment 11: 2573-2578.

Hossain MA, Sen M, Jewel MIU \& Kabir MA (2011) Propagation of Flacourtia jangomas: an approach towards the domestication of a wild fruit species in Bangladesh. Dendrobiology 65: 63-71.

Hossain MA, Arefin MK, Khan, BM \& Rahaman MA (2005a) Effect of different seed treatments on germination and seedling growth attributes of a medicinal plant Bohera (Terminalia belerica) in Nursery. International Journal of Forest Usufructs Management 6: 28-37.

Hossain MA, Arefin MK, Khan BM \& Rahaman MA (2005b) Effects of seed treatments on germination and seedling growth attributes of horitoki (Terminalia chebula) in the nursery. Research Journal of Biological Sciences 1: 135-141.

Hossain MA, Islam MA \& Hossain MM (2004) Rooting ability of cuttings of Swietenia macrophylla King and Chukrasia velutina Wight et Arn as influenced by exogenous hormone. International Journal of Agriculture and Biology 6: 560-564.

Hossain MA, Rahman MM \& Kamaluddin M (2002) Rooting ability of cuttings as influenced by Etiolation of Stockplants and auxin. SUST Studies 4: 55-65.

Hoveka L (2017) Entada rheedii Spreng., Family: Fabaceae. South African National Biodiversity Institute, Cape Town. http://pza.sanbi.org/entada-rheedii.

Janardhanan K \& Nalini K (1991) Studies on the tribal pulse, Entada scandens Benth: chemical composition and antinutritional factors. Journal of Food Science and Technology 28: 249-251.

Janardhanan K, Vadivel V \& Pugalenthi M (2003) Biodiversity in Indian under-exploited / tribal 
pulses. Improvement strategies for Leguminosae Biotechnology (ed. by PK Jaiwal \& RP Singh) Kluwer Academic Publishers, The Netherlands, pp. 353-405.

Kamaluddin M (1996) Clonal propagation of Eucalyptus and Acacia hybrid by stem cuttings. Research Report. Forestry Division, Bangladesh Agricultural Research Council, Dhaka.

Kamaluddin M \& Ali M (1996) Effect of leaf area and auxin on rooting and growth of rooting stem cuttings of Neem. New Forests 12: 11-18. doi:10.1007/BF00029979.

Kamaluddin M, Miah ME \& Pandit S (1998) Propagation of Chickrassia velutina by cutting: response to applied auxin and shoot production. Malaysian Forester 61: 92-100.

Kumar N, Handa AK, Dev I, Ram A, Uthappa AR, Shukla A \& Chand L (2018) Effect of pre-sowing treatments and growing media on seed germination and seedling growth of Albizia lebbeck (L.) Benth. Journal of Applied and Natural Science 10: 860-863. doi.org/10.31018/jans.v10i3.1750.

Lee CC \& Bilderback TE (1990) Propagation of Heptacodium jasminoides Airy-Shaw by softwood and semi-hardwood cuttings. Journal of Environment and Horticulture 8: 121-123. doi:10.24266/07382898-8.3.121.

Luckow M (2005) Tribe Mimoseae: Legumes of the world (ed. by G Lewis, B Schrire, B Mackinder \& M Lock) Royal Botanic Gardens, Kew, UK, pp. 163-183.

Mohan VR \& Janardhanan K (1993) Chemical and nutritional evaluation of raw seeds of the tribal pulses. Parkia roxburghii G. Don and Entada phaseoloides (L.) Merr. International Journal of Food Science and Nutrition 44: 47-53. doi:10.3109/09637489309017422.

Missanjo E, Chioza A \& Kulapani C (2014) Effects of different pretreatments to the seed on seedling emergence and growth of Acacia polyacantha. International Journal of Forestry Research: 583069. doi:10.1155/2014/583069.

Negash L (2002) Successful vegetative propagation techniques for the threatened African pencil cedar (Juniperus procera Hoechst. ex Endl.). Forest Ecology and Management 161: 53-64. doi:10.1016/ S0378-1127(01)00501-1.

Nongrum A \& Kharlukhi L (2013) Effect of seed treatment for laboratory germination of Albizia chinensis. Journal of Forestry Research 24: 709713. doi:10.1007/s11676-013-0408-z.

Nzowa LK, Teponno RB, Tapondjou LA, Verotta L, Liao Z, Graham D, Zink MC \& Barboni L (2013) Two new tryptophan derivatives from the seed kernels of Entada rheedei: effects on cell viability and HIV infectivity. Fitoterapia 87: 37-42. doi:10.1016/j.fitote.2013.03.017.
Ohashi H, Huang T \& Ohashi K (2010) Entada (Leguminosae subfam. Mimosoideae) of Taiwan. Taiwania 55: 43-53.

Okba MM, Soliman FM, EL Deeb KS \& Yousif MF (2013) Botanical study, DNA fingerprinting, nutritional values and certain proximates of Entada rheedii Spreng. International Journal of Pharmacy and Pharmaceutical Sciences 5: 31-329.

Rajkumar MH \& Rajanna MD (2011) Ex-situ conservation of climbing plants at University of Agricultural sciences, Bangalore, Karnataka. Recent Research in Science and Technology 3: 18-20.

Rosa LS (1997) Promotion of rooting in stem cuttings of Tschi-branco (Sclerolobium paniculatum) by application of different concentrations of indole-3-butyric acid. Boletim da Faculdade de Ciencies Agraries do Para 28: 81-91.

Siddhuraju P, Becker K \& Makkar HPS (2001) Chemical composition, protein fractionation, essential amino acid potential and antimetabolic constituents of an unconventional legume, Gila bean (Entada phaseoloides Merrill) seed kernel. Journal of Science of Food and Agriculture 82: 192-202. doi:10.1002/jsfa.1025.

Subbaiah CC (1982) Effect of pre-soaking in organic solvents on seed germination and seedling growth of cashew. Scientia Horticulturae 18: 137-142. doi:10.1016/0304-4238(82)90128-5.

Tchoundjeu Z, Mpeck MLN, Asaah E \& Amougou A (2004) The role of vegetative propagation in the domestication of Pausinystalia johimbe ( $\mathrm{K}$. Schum), a highly threatened medicinal species of West and Central Africa. Forest Ecology and Management 188: 175-183. doi:10.1016/j.foreco.2003.07.010.

Vadivel V, Pugalenthi M \& Megha S (2008) Biological evaluation of protein quality of raw and processed seeds of Gila Bean (Entada scandens Benth.). Tropical and Subtropical Agroecosystems 8: 125-133.

Vijayakumari K, Siddhuraju P \& Janardhanan K (1993) Chemical composition and nutritional potential of the tribal pulse, Bauhinia malabarica Roxb. Plant Foods for Human Nutrition 44: 291298. doi:10.1007/BF01088325.

Wangchuk P, Yeshi K \& Jamphel K (2017) Pharmacological, ethnopharmacological, and botanical evaluation of subtropical medicinal plants of Lower Kheng region in Bhutan. Integrative Medicine Research 6: 372-387. doi:10.1016/j. imr.2017.08.002.

Yang SZ, Hueng SH, Huang JC \& Chiang SH (2005) The taxonomy of Entada genus in Taiwan. Quarterly Journal of Chinese Forestry 38: 255-266.

Zaman SMH, Rahim K \& Howlader M (1983) Simple lessons from biometry. Bangladesh Agricultural Research Institute, Gazipur, Bangladesh, pp. 77-90. 